\section{Kidney \\ Blood Pressure Research}

Kidney Blood Press Res 2013;37:332-345

DOI: $10.1159 / 000350161$
Published onlIne: September 23, 2013

(C) 2013 S. Karger AG, Basel

www.karger.com/kbr

$1423-0143 / 13 / 0375-0332 \$ 38.00 / 0$

Accepted: July 26, 2013

This is an Open Access article licensed under the terms of the Creative Commons AttributionNonCommercial 3.0 Unported license (CC BY-NC) (www.karger.com/OA-license), applicable to the online version of the article only. Distribution permitted for non-commercial purposes only.

\title{
The Role of Th17/IL-17 in the Pathogenesis of Primary Nephrotic Syndrome in Children
}

\author{
Li Wang Qiu Li Lijia Wang Cuicui Li Haiping Yang Xiaoli Wang Hong Tao \\ Department of Nephroimmunology, Children's Hospital of Chongqing Medical University, Chongqing \\ 400014, People's Republic of China
}

\section{Key Words}

Nephrotic syndrome $\bullet$ Th17 cells $・$ IL-17 $•$ Podocyte $・$ Apoptosis $・$ Podocalyxin

\begin{abstract}
Background: This work aims to explore the role of Th17 and IL-17 signaling in the pathogenesis of primary nephrotic syndrome (PNS) in children and podocyte injury, children with PNS were divided into minimal change nephrotic syndrome (MCNS) and non-minimal change nephrotic syndrome [NMCNS, including mesangial proliferative glomerulonephritis (MsPGN) and focal segmental glomerulosclerosis (FSGS)]. Methods: Flow cytometry (FCM) was used to observe the circulating frequency of Th17 cells and the apoptosis of podocytes by annexinVFITC/PI. Serum IL-1 $\beta$ and IL- 6 levels were measured using enzyme-linked immunosorbent assay. The Fas and FasL expressions in podocytes were examined by FCM analysis using a direct immunofluorescence method. Reverse transcription polymerase chain reaction was applied to measure the mRNA expressions of RORc, IL-23p19, Nephrin, WT1, Synaptopodin, Podocalyxin, Fas, and FasL. The IL-17 and IL-1 $1 \beta$ expression in renal biopsy tissue was detected by immunohistochemistry. The expressions of WT1, Caspase 8, and Caspase 3 in podocyte cell culture were also measured using immunocytochemistry. Results: Circulating frequencies of Th17 cells, mRNA levels of RORc and IL-23p19, and serum levels of IL- 6 and IL-1 $\beta$ were higher in the MCNS and NMCNS groups than in the control group (all $P<0.05$ ), and were higher in the NMCNS group than in the MCNS group (all $P<0.05$ ). The expressions of IL-17 and IL-1 $\beta$ in renal biopsy tissue were higher in the MCNS, MsPGN, and FSGS groups than in the control group (all $P<0.05$ ). Recombinant murine IL-17 (rmIL-17) had no effect on the expressions of Nephrin, Synaptopodin, and WT1 of mouse podocytes, but caused an decrease in the expression of podocalyxin as well as promoted apoptosis in a dose- and time-dependent fashion. Moreover, rmIL-17 increased the expression of Fas, Casepase-8, and Casepase-3, but had no effect on that of FasL. Conclusion: Th17/IL-17 may contribute to the pathogenesis of PNS by decreasing the podocalyxin level and inducing podocyte apoptosis.
\end{abstract}

Li Wang and

Qiu Li (corresponding author)
Department of Nephroimmunology, Children's Hospital of Chongqing Medical

University, Chongqing 400014 (People's Republic of China)

Tel. 023-63603929, Fax 023-63603929

E-Mail cnliwang@163.com and E-Mail liwangyx@yeah.net 


\section{Kidney Blood Pressure Research}

Kidney Blood Press Res 2013;37:332-345

\begin{tabular}{l|l}
\hline DOI: $10.1159 / 000350161$ & C 2013 S. Karger AG, Basel
\end{tabular}

Published onlıne: September 23, 2013

www.karger.com/kbr

Wang/Li/Wang/Li/Yang/Wang/Tao: Role of Th17/IL-17 in the Pathogenesis of PNS

\section{Introduction}

Primary nephrotic syndrome (PNS) is a common glomerular disease in children and is one of the main causes of chronic renal failure in children in China [1]. PNS can be classified by renal pathology into minimal change nephrotic syndrome (MCNS), which accounts for $80 \%$ of cases, and non-minimal change nephrotic syndrome (NMCNS), which includes focal segmental glomerulosclerosis (FSGS), mesangial proliferative glomerulonephritis (MsPGN), and membranoproliferative glomerulonephritis. In clinical practice, MCNS is sensitive to glucocorticoid therapy [2], whereas NMCNS is typically insensitive, even mild diseases can progress to end-stage renal diseases [3]. The clinical manifestations of PNS are heavy proteinuria, hypoalbuminemia, hyperlipidemia, and edema. Despite well-defined clinical descriptions, the underlying pathogenesis that leads to extensive proteinuria remains unclear. In 1974, Shalhoub [4] discovered that the pathogenesis of MCNS is connected to T-cell dysfunction. Since then, many researchers have demonstrated that T cells and Th1/ Th2 imbalance play a vital role in the pathogenesis of PNS in children. Data are varied, with some reports supporting the role of Th1 and related cytokines, suggesting IL-2, sIL-2R, and interferon-gamma in patients with steroid sensitivity NS give further evidence that a Th1 pattern is involved in the pathogenesis of NS [5]. Other studies support the role of Th2 and related cytokines in promoting the development of PNS [6]. These studies have concluded that, prior to treatment, Th1 and Th2 cell activities provide a useful tool to evaluate the probability of steroid sensitivity in patients with PNS. In steroid sensitivity children with NS they had found the cytokine synthesis indicating the predominance of Th2 activity. But other conclude that there is no significant skew of Th1/Th2 balance in childhood PNS [7]. So Th1/Th2 balance can not explain the pathogenesis of PNS. More recently, the Th17 cell, which secretes factors such as IL-17, L-22, and IL-23, was discovered and implicated in the pathogenesis of inflammatory and autoimmune diseases. Shao [8] and our preliminary experiments suggest that Th17 and related factors may take part in the leakage of proteinura in PNS, but its mechanism is still unknown.

In this research, we examined the role of the Th17 pathway in MCNS and NMCNS and how IL-17 contributes to podocyte injury.

\section{Material and Methods}

\section{Case collection}

We enrolled 38 children with PNS. 20 had MCNS (15 boys and 5 girls, mean age 5.2 years) and 18 had NMCNS [11 boys and 7 girls, mean age 8.9 years, including MsPGN $(n=10)$ and FSGS $(n=8)]$. Twenty healthy children were selected as controls (14 boys and 6 girls, mean age 7.4 years). Renal biopsy samples were obtained. Control renal samples came from normal tissue adjacent to renal tumor, and normal renal tissue was confirmed by light microscopy. This study was conducted in accordance with the Helsinki Declaration and with the approval of the Ethics Committee of Chongqing Medical University. Written informed consent was obtained from all participants.

\section{Blood samples}

Fasting blood samples were collected into sterile sodium heparin tubes. Peripheral blood mononuclear cells (PBMCs) were prepared by using Ficoll density gradient (TBD, China) for flow cytometric analysis and real-time reverse transcription polymerase chain reaction (RT-PCR). Plasma was obtained after centrifugation at $1500 \mathrm{rpm}$ for $10 \mathrm{~min}$ and stored at $-20{ }^{\circ} \mathrm{C}$ for cytokine measurements.

\section{Biochemical analysis}

The 24-h urinary protein excretion was measured using the Coomassie brilliant blue method. Serum albumin (ALB), total cholesterol (TC), triglyceride (TG), low-density lipoprotein (LDL), and creatinine (Cr) were measured using an automatic biochemical analyzer (Dimension RxL, Dade Behring, USA). 


\section{Kidney Blood Pressure Research}

\section{Flow cytometric analysis}

Cell preparation: For Th17 analysis, PBMCs were cultured in a 24 -well plate at a density of $1 \times 10^{6}$ cells $/ \mathrm{ml}$ in RPMI-1640 culture medium with $100 \mathrm{U} / \mathrm{ml}$ penicillin, $100 \mu \mathrm{g} / \mathrm{ml}$ streptomycin, $2 \mathrm{mM}$ glutamine, and $10 \%$ heat-inactivated fetal calf serum (Gibco, CA, USA). The cells were stimulated under a $5 \% \mathrm{CO}_{2}$ environment with phorbol myristate acetate (PMA, $50 \mathrm{ug} / \mathrm{ml}$, Sigma, MO, USA), ionomycin ( $2 \mu \mathrm{M}, \mathrm{BD}, \mathrm{USA}$ ), and monensin ( $750 \mathrm{umol} / \mathrm{l}, \mathrm{BD}, \mathrm{USA})$ at $37^{\circ} \mathrm{C}$. After $4 \mathrm{~h}$ in culture, the cells were transferred to sterile tubes, centrifuged at $2500 \mathrm{rpm}$ for $5 \mathrm{~min}$, and then washed twice with $0.01 \mathrm{M}$ phosphate-buffered saline (PBS).

Surface and intracellular staining: For Th17 analysis, the cells were incubated with phycoerythrin (PE) anti-human CD8 (eBioscience, USA) and PECy5-anti-human CD3 (Jingmei, Shenzhen, China) at $4{ }^{\circ} \mathrm{C}$ for 30 min. After two washings, the cells were fixed using Fix\&perm (BD, USA) at $4{ }^{\circ} \mathrm{C}$ for $15 \mathrm{~min}$. The membranes were broken and the cells were stained with FITC anti-human IL-17A (EB, USA), which labels Th17 cells. Isotype controls were given to enable correct compensation and to confirm antibody specificity. Stained cells were analyzed by flow cytometric analysis.

\section{ELISA}

The plasma levels of IL-1 $\beta$ and IL- 6 were measured using enzyme-linked immunosorbent assay (ELISA) following the manufacturer's instructions (all ELISA kits from Sizhengbo, Beijing, China). The minimal detectable concentrations were $2 \mathrm{pg} / \mathrm{ml}$ for IL- $1 \beta$ and $1 \mathrm{pg} / \mathrm{ml}$ for IL-6. All samples were measured in duplicate.

\section{Renal histopathological examination}

After the paraffin-fixed renal tissue was cut to $3 \mu \mathrm{m}$ thickness, the tissue was deparaffinized and hydrated, followed by staining with hematoxylin and eosin (H\&E) or periodic acid-Schiff (PAS). The glomerulosclerosis index (GSI) was analyzed as previously described [9].

\section{Immunohistochemical staining}

First, $3 \mu \mathrm{m}$-thick sections of deparaffinized renal tissue were placed in 3\% hydrogen peroxide for 15 min to inactivate the endogenous peroxidase. The sections were heated twice in $0.01 \mathrm{M}$ of sodium citrate buffer ( $\mathrm{pH}$ 6.0) for $5 \mathrm{~min}$ in a microwave oven. After being returned to room temperature, the sections were cultured with 1:100 IL-17 (Santa Cruz, CA, USA), 1:100 IL-1 $\beta$ (Santa Cruz, USA), and 1:200 FasL rabbit polyantibody (Boaoshen, China) overnight at $4{ }^{\circ} \mathrm{C}$. PBS was selected as the negative control. After washing with $0.01 \mathrm{M}$ PBS, the sections were cultured with HRP-mouse-anti-rabbit antibody for $30 \mathrm{~min}$ at $37^{\circ} \mathrm{C}$. Finally, 3,3' Diaminobenzidine (DAB) (Zhongbin, China) was used as chromogenic agent, with brown considered as a positive stain. ImageProPlus 5.1 was used to analyze average optical density.

\section{Cell line and cell culture}

The H-2Kb-tsA58 transgenic immortalized mouse podocyte cell line, kindly provided by Professor P. Mundel of the Mount Sinai School of Medicine, New York, USA, was cultured as previously described [10]. Briefly, podocytes were grown in culture flasks (Corning, NY, USA) coated with collagen type I (Sigma, USA) in an RPMI-1640 medium (Gibco, USA) with 10\% fetal bovine serum (Gibco, USA), 2 mmol/l glutamine, $100 \mathrm{U} / \mathrm{ml}$ penicillin, $100 \mu \mathrm{g} / \mathrm{ml}$ streptomycin (Gibco, USA), $5 \times 10^{-3} \mathrm{mg} / \mathrm{ml}$ insulin, $5 \times 10^{-3} \mathrm{mg} / \mathrm{ml}$ transferrin, $5 \times 10^{-6} \mathrm{mg} / \mathrm{ml}$ sodium selenite (Sigma, USA), and $100 \mathrm{U} / \mathrm{ml}$ mouse recombinant interferon- $\gamma(\mathrm{R} \& \mathrm{D}, \mathrm{MN}$, USA) at $33{ }^{\circ} \mathrm{C}$ in $5 \% \mathrm{CO}_{2}$. Then cells were cultured in the medium without IFN- $\gamma$ at $37{ }^{\circ} \mathrm{C}$ for two weeks to induce differentiation. Cells between passages 15 and 25 were used for these experiments.

\section{Annexin V-FITC/PI double staining}

Differentiated podocytes were seeded at $1 \times 10^{5}$ cells $/ \mathrm{ml}$ in a 24 -well plate (Corning) precoated with type I collagen. For dose and time studies, podocytes were cultured in a total volume of $1 \mathrm{ml}$ for increasing times of $12,24,48$, and $72 \mathrm{~h}$ in 24 -well plates in RPMI 1640 with $10 \% \mathrm{FCS}$ at $37{ }^{\circ} \mathrm{C}, 5 \% \mathrm{CO}_{2}$, in the presence of increasing concentrations $(0,1,10,50,100 \mathrm{ng} / \mathrm{ml})$ of recombinant human IL-17 (rmIL-17, R\&D, USA). Flow cytometry (FCM) was used to observe apoptotic podocytes through annexinV-FITC/PI staining (Kai-ji, Nanjing, China). 


\section{Kidney \\ Blood Pressure Research}

RT-PCR

Total RNA was extracted with an RNA extraction kit following the manufacturer's instructions (TIANGEN, China). RNAs were reverse-transcribed following the manufacturer's instructions (TAKARA, China). The RT-PCR was performed in a $25 \mu$ reaction solution system consisting of $12.5 \mu \mathrm{L}$ SYBR Premix Taq $(2 \times 0.5 \mu \mathrm{l}), 0.5 \mu \mathrm{l}$ RT-PCR forward Primer $(10 \mu \mathrm{M}), 0.5 \mu \mathrm{l}$ RT-PCR reverse Primer $(10 \mu \mathrm{M})$, and $9.5 \mu \mathrm{L}$ $\mathrm{ddH}_{2} \mathrm{O}$ (TAKARA, China). The primers were purchased from Invitrogen (USA). The primer sequences were as follows:

RORc: sense: 5'TGT CCC GAG ATG CTG TCA AGT TC3', anti-sense: 5'GGT TCC TGT TGC TGC TGT TGC3'; IL-23p19: Sense: 5'CTC CGC TTC AAA ATC CTT CGC3', anti-sense: 5'CTG GGG TGG TAG ATT TAT CTT GGC 3'; Nephrin: Sense: 5' GGG AAG ACG AGG AGG AAC TGA AC3', anti-sense: 5'AAT CGG ACA ACA AGA CGA ACC AG3'; Synaptopodin: Sense: 5'GGC TAT CTG CCA GAG AAT GGA GTC3', anti-sense: 5'GTG AGA CAG TGC GTG ATG GAG TG3'; Podocalyxin: Sense: 5'GCA ACA GTC TAT GGC GTC TAC AGT G3', anti-sense: 5' TGT GAG GTT CAG AAT AAG GAG TTC C3'; WT1: Sense: 5'AAC CAC GGC ACA GGG TAT GAG3', anti-sense: 5'CAT CCT GAA TGC CTC GGA AGA C3'; Fas: Sense: 5'CCA TGC ACA GAA GGG AAG GAG TAC3', anti-sense: 5' GCC AGG AGA ATC GCA GTA GAA GTC3'; FasL: Sense: 5'GGA AGA CAC ATA TGG AAC CGC TC 3', anti-sense: 5' GAA GTA CAA CCC AGT TTC GTT GAT C3'.

The sizes of the RT-PCR products were $109 \mathrm{bp}$ for RORc, $115 \mathrm{bp}$ for IL-23p19, $172 \mathrm{bp}$ for Nephrin, $157 \mathrm{bp}$ for Synaptopodin, $103 \mathrm{bp}$ for WT1, 85 bp for Podocalyxin and FasL, and 168 bp for Fas. The RT-PCR conditions for RORc, IL-23p19, Synaptopodin, WT1, and Nephrin were as follows. The samples were heated to $94{ }^{\circ} \mathrm{C}$ for $4 \mathrm{~min}$ followed by 39 temperature cycles. Each cycle included denaturation at $94{ }^{\circ} \mathrm{C}$ for $20 \mathrm{~s}$, annealing at $60{ }^{\circ} \mathrm{C}$ for $10 \mathrm{~s}$, and extension at $72{ }^{\circ} \mathrm{C}$ for $20 \mathrm{~s}$, followed by a melt curve from $65{ }^{\circ} \mathrm{C}$ to $95^{\circ} \mathrm{C}$ in increments of $0.5^{\circ} \mathrm{C}$ for $5 \mathrm{~s}$ durations.

The samples were analyzed by the Gene Expression Analysis for icycler iQ RT-PCR Detection System (v 1.10) (BIO-RAD, USA). For each sample, mRNA expression level was normalized to the GAPDH level.

Fas and FasL expressions in podocytes

Differentiated podocytes were seeded at $5 \times 10^{5}$ cells $/ \mathrm{ml}$ into six-well medium plates precoated with type I collagen. The cells were divided into a control group and a $100 \mathrm{ng} / \mathrm{ml} \mathrm{rmIL-17-induced} \mathrm{group.} \mathrm{The}$ two groups were incubated at $37{ }^{\circ} \mathrm{C}, 5 \% \mathrm{CO}_{2}$ for three days. The Fas and FasL expressions in podocytes were detected by FCM using direct immunofluorescence. Briefly, $100 \mu$ l containing $10^{6}$ cells were divided into control and unknown groups. Then, $30 \mu \mathrm{l}$ (1:50) FITC-Fas (Boaoshen, China), FITC-FasL (Boaoshen, China), and isotype control were added. The solution was mixed and incubated at $4{ }^{\circ} \mathrm{C}$ for $30 \mathrm{~min}$, and then centrifuged at $1200 \mathrm{rpm}$ at $4{ }^{\circ} \mathrm{C}$ for $10 \mathrm{~min}$. Fixative liquid was added, the samples were mixed, and then FCM was performed.

\section{Immunocytochemistry}

Differentiated podocytes were seeded at $1 \times 10^{4}$ cells $/ \mathrm{cm}^{2}$ in $1.3 \mathrm{~cm}^{2}$ glasses precoated with type I collagen. The cells were divided into a control group and a $100 \mathrm{ng} / \mathrm{ml} \mathrm{rmIL-17-induced} \mathrm{groups.} \mathrm{Two} \mathrm{groups}$ were incubated at $37^{\circ} \mathrm{C}, 5 \% \mathrm{CO}_{2}$ condition for three days. The sections were washed in $0.01 \mathrm{M}$ PBS twice and fixed with $4 \%$ paraformaldehyde for $30 \mathrm{~min}$. The sections were then treated with $0.2 \%$ Triton X-100 at room temperature for $10 \mathrm{~min}$. After washing, the sections were incubated with antibodies for WT1 (1:150, Santa Cruz, USA), Caspase 8 (1:100, Boaoshen, China), and Caspase 3 (1:60, Millipore, MA, USA) at $4{ }^{\circ} \mathrm{C}$ overnight. The sections were then washed with PBS and incubated with HRP-goat-anti-rabbit-IgG antibody at $37{ }^{\circ} \mathrm{C}$ for 30 min. Finally, DAB was used as chromogenic agent with brown pigment deposition considered as a positive stain. ImageProPlus 5.1 software was used for analysis.

\section{Statistical analysis}

SPSS 13.0 was used for statistical analysis. Data were expressed as mean \pm SD. Differences between experimental groups were evaluated by one-way ANOVA or $t$ - test. A value of $P<0.05$ was regarded as a significant difference. 


\section{Kidney Blood Pressure Research}

Fig. 1. In MCNS and NMCNS groups,Serum albumin (ALB) was lower than that in controls,total cholesterol (TC), low density lipoprotein (LDL), and amount of $24 \mathrm{hr}$ proteinuria were higher in the PNS groups than those in controls, whereas total triglyceride (TGs) and serum creatinine (Cr) indicated no difference. Values represent mean \pm standard error. Ctr stands for control, MCNS for minimal change nephrotic syndrome, NMCNS for non-minimal change nephrotic syndrome. ${ }^{*} P<$ 0.05 vs. Ctr.

\section{Kidney Blood Press Res 2013;37:332-345}

\begin{tabular}{l|l}
\hline DOI: $10.1159 / 000350161$ & C 2013 S. Karger AG, Basel \\
www.karger.com/kbr
\end{tabular}

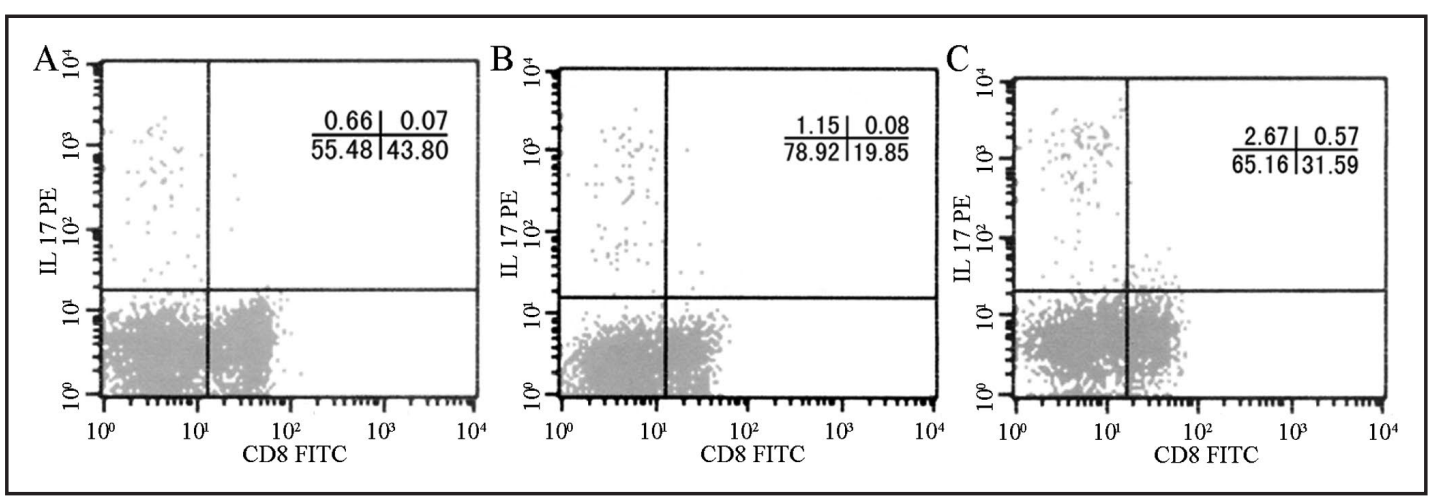

Fig. 2. More Th17 cells (CD3+CD8-IL-17+ cells) were circulating in the MCNS and NMCNS groups compared with those in the control group. A: control group, B: MCNS group, and C: NMCNS group.

\section{Results}

\section{Biochemical findings}

The serum ALB levels in the MCNS and NMCNS groups were lower $(P<0.05)$ compared with the control group. The concentrations of serum LDL, TC and $24 \mathrm{~h}$ urine protein in the two groups were higher than those in the control group $(P<0.01)$. There was no statistically significant difference in the serum ALB, LDL, TC and $24 \mathrm{~h}$ urine protein between the MCNS and NMCNS groups (Fig. 1, $P>0.05$ ).

\section{Th17 cells in PBMC with PNS}

The number of CD 4 factors was shown to decrease when the T cells were stimulated by PMA (Sigma, USA), and thus, $\mathrm{CD}^{+}{ }^{+} \mathrm{CD} 8 \mathrm{IL}^{-} 7^{+}$represent Th17 cells. There were more circulating Th17 cells in the MCNS and NMCNS groups than in the control group $(P<0.01)$. The amount of circulating Th17 cells in the NMCNS group was significantly higher than that in the MCNS group (Fig. 2, Table. $1, P<0.01$ ).

mRNA expression of RORc and IL-23p19 in PBMC with PNS

The mRNA expressions of RORc and IL-23p19 in PBMC of MCNS and NMCNS groups were higher than that in the control group $(P<0.01)$. The mRNA expression of RORc and IL-23p19 in PBMC of the NMCNS group was higher than that in the MCNS group (Fig. 3, $P<$ $0.01)$. 


\section{Kidney Blood Pressure Research}

Table 1. The expression of $\mathrm{T}$ cell expressing IL-17 in PBMC $(x \pm s, \%)$

\begin{tabular}{|c|c|c|}
\hline Group & Th17(CD3+ CD8-IL17+) & Tc17(CD3+ CD8+IL17+) \\
\hline Control & $1.19 \pm 0.45$ & $0.36 \pm 0.14$ \\
\hline MCNS & $1.59 \pm 0.72^{\mathrm{a}}$ & $0.34 \pm 0.26$ \\
\hline NMCNS & $2.42 \pm 1.16^{\mathrm{ab}}$ & $0.36 \pm 0.23$ \\
\hline \multicolumn{3}{|c|}{$\mathrm{CD}^{+}$CD8-IL17+ represent Th17 cell a $P<0.05$ vs control, b $P<$} \\
\hline \multicolumn{3}{|c|}{0.05 vs MCNS. } \\
\hline
\end{tabular}

Fig. 3. With regard to the level of RORc and IL-23p19 mRNA from RT-PCR relative to the housekeeping gene GAPDH in PBMC, the values represent mean \pm standard error. ${ }^{*} P<0.05$ vs Ctr; $\# P<0.05$ vs. MCNS.

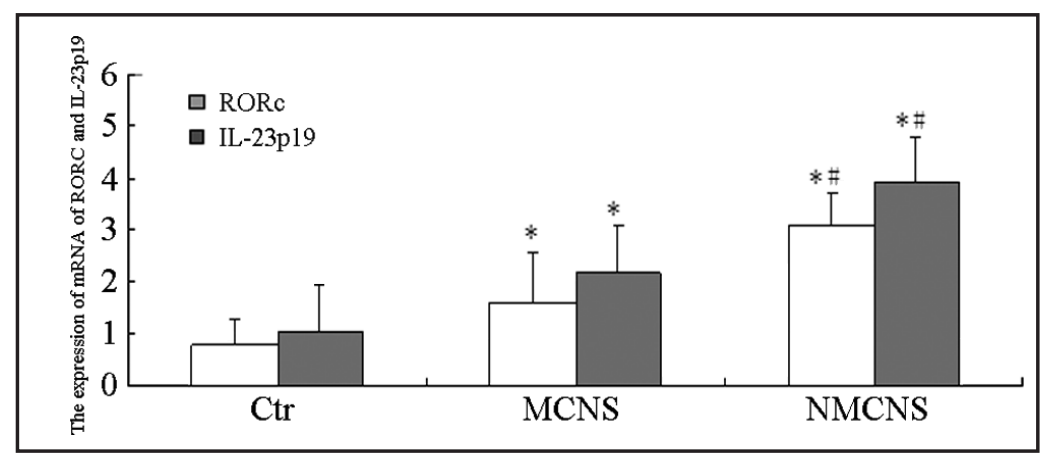

Fig. 4. Serum level of IL$1 \beta$ and IL- 6 by ELISA. The values represent mean \pm standard error. ${ }^{*} P<0.05$ vs. Ctr; $\# P<0.05$ vs. MCNS.

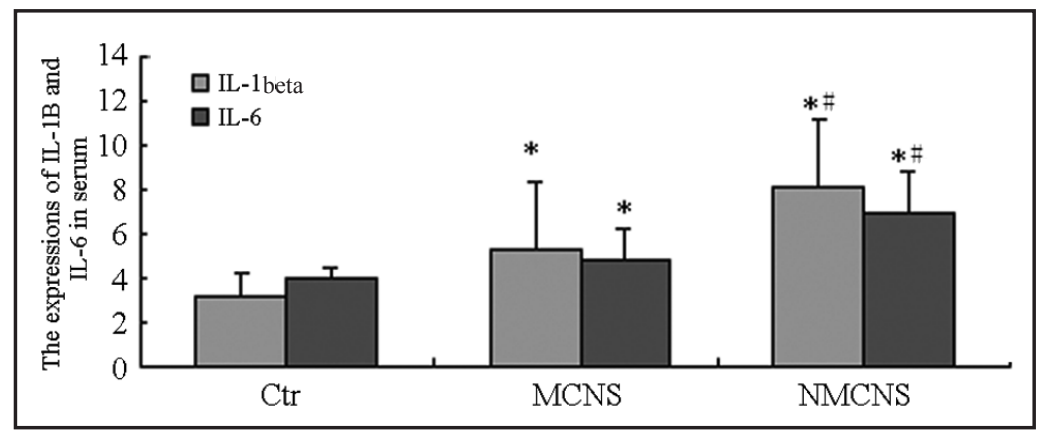

$I L-1 \beta$ and IL-6 expressions in serum by ELISA

There were elevated expression levels of IL-1 $\beta$ and IL- 6 in the serum from the MCNS and NMCNS groups $(P<0.05)$ compared with the control group. The expression levels of IL$1 \beta$ and IL- 6 in the serum from the NMCNS group were also higher than in the MCNS group (Fig. $4, P<0.05$ ).

Histopathological findings and glomerulosclerosis index

Under light microscopy, kidney biopsy sections from the control and MCNS groups were histologically normal in appearance of the glomerulus and renal tubules (Fig. 5 A-B, E-F). In the MsPGN group, glomerular change was observed, which consisted of the proliferation of mesangial cells and increased mesangial matrix (Fig. $5 \mathrm{C}, \mathrm{G}$ ), whereas there was obvious glomerulosclerosis in the FSGS group (Fig. 5 D, H). We analyzed the GSI and found that the GSI of the renal tissue in the MsPGN $(1.65 \pm 1.02) \%$ and FSGS $(4.55 \pm 2.08) \%$ groups were higher than that in the control $(0.23 \pm 0.12) \%$ and MCNS $(0.24 \pm 0.12) \%$ groups $(P<0.01)$. The GSI of FSGS was higher than that in the MsPGN group $(P<0.05)$. No statistically significant difference was observed in the GSI of the renal biopsy between the control and MCNS groups $(P>0.05)$. 


\section{Kidney Blood Pressure Research}

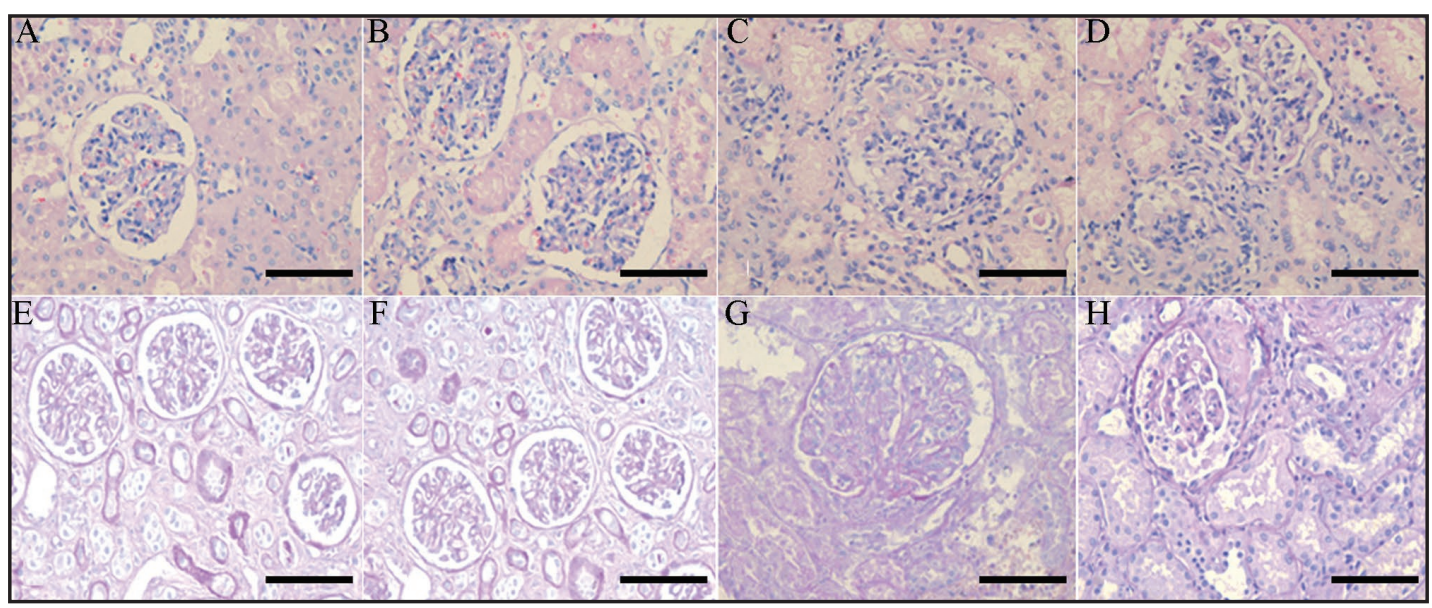

Fig. 5. Kidney biopsy tissue from the control group (A, E), MCNS group (B, F), MsPGN group (C, G), and FSGS group (D, H) under light microscope with H\&E staining (A-D) and PAS staining (E-H), with magnification bar $=50 \mu \mathrm{m}$.

Fig. 6. IL-1 $\beta$ and IL-17 expression in kidney biopsy tissue from children with PNS; ${ }^{*} P<0.05$ vs. ctr; $\# P<0.05$ vs. MCNS; $i$ is $<0.01$ vs. MsPGN.

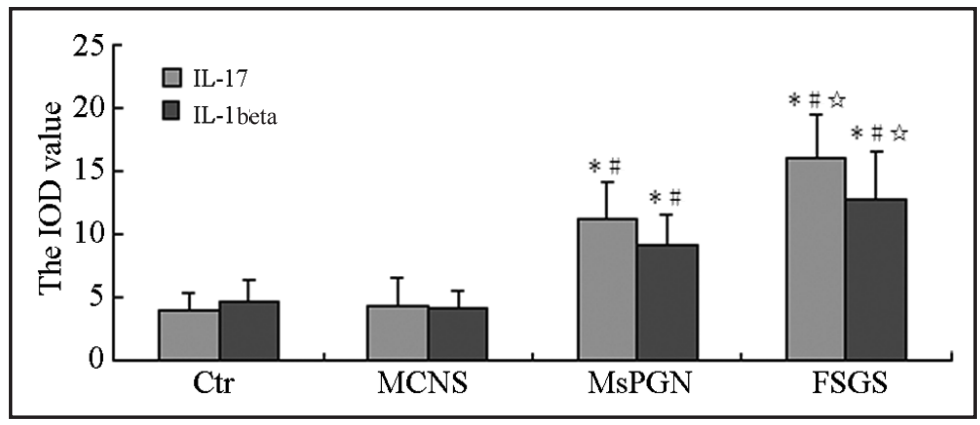

Renal immunohistochemistry of $I L-1 \beta$ and $I L-17$

Only a small amount of staining was observed for IL-1 $\beta$ and IL-17 in the control and MCNS groups, but there was obviously increased staining in the MsPGN and FSGS groups $(P$ $<0.01$ ). Renal expressions of IL-1 $\beta$ and IL-17 were higher in the FSGS samples than in the MsPGN samples (Fig. 6, $P<0.01$ ).

Relativity analysis of $I L-17, I L-1 \beta$, and GSI in kidney

In MsPGN, no connection was observed between IL-17(11.19 \pm 2.93$)$ and GSI $(1.65 \pm 1.02)$ $(\gamma=0.15, P=0.55)$. In FSGS, positive relativity was observed between IL-17(15.99 \pm 3.32$)$ and $\operatorname{IL}-1 \beta(12.71 \pm 3.85)(\gamma=0.74, P=0.01)$ and IL-17 and $\operatorname{GSI}(4.55 \pm 2.08)(\gamma=0.65, P=0.04)$.

\section{Effect of rmIL-17 on podocyte apoptosis}

As shown in Table 2 and Figure 7, rmIL-17 had a time- and dose-related pro-apoptotic effect on podocytes. In the $12 \mathrm{~h}$ and $24 \mathrm{~h}$ groups, different concentrations of rmIL-17 had no impact on podocyte apoptosis $(P>0.05)$. However, in the $48 \mathrm{~h}$ and $72 \mathrm{~h}$ groups, the rate of podocyte apoptosis increased with increasing rmIL-17 concentration $(P<0.05)$. In $1 \mathrm{ng} /$ $\mathrm{ml}$ and $10 \mathrm{ng} / \mathrm{ml} \mathrm{rmIL-17}$ group, different time had no impact on podocyte apoptosis $(P$ $>0.05$ ),but in $50 \mathrm{ng} / \mathrm{ml}$ and $100 \mathrm{ng} / \mathrm{ml} \mathrm{rmIL-17}$ group, the rate of podocyte apoptosis increased with increasing time $(P<0.05)$. So we chose $100 \mathrm{ng} / \mathrm{ml}$ of rmIL-17 and $72 \mathrm{~h}$ for later experiments.

Effects of rmIL-17 on mRNA of nephrin, WT1, synaptopodin, podocalyxin, Fas, and FasL in podocytes

The mRNA expression of Fas in podocytes exposed to $100 \mathrm{ng} / \mathrm{ml} \mathrm{rmIL-17} \mathrm{in} 72 \mathrm{~h}$ was higher than in control podocytes exposed to the vehicle alone $(P<0.01)$,but the mRNA 


\section{Kidney \\ Blood Pressure Research}

Table 2. Time course of the effect of different rmIL-17 concentration on podocyte apoptosis ( $n=3, x \pm s$ )

\begin{tabular}{|c|c|c|c|c|c|}
\hline & $12 \mathrm{~h}$ & $24 \mathrm{~h}$ & $48 \mathrm{~h}$ & $72 \mathrm{~h}$ & $\mathrm{~F}$ value \\
\hline Control & $3.47 \pm 1.06$ & $3.67 \pm 0.90$ & $2.73 \pm 0.49$ & $6.28 \pm 1.75$ & 5.06 \\
\hline 1ng/ml rmIL-17 & $4.56 \pm 1.74$ & $3.34 \pm 1.16$ & $5.28 \pm 1.00^{\mathrm{ae}}$ & $12.39 \pm 0.90^{\text {aef }}$ & 21.96 \\
\hline 10ng/ml rmIL-17 & $4.62 \pm 0.57$ & $4.12 \pm 0.22$ & $6.21 \pm 1.19$ abe & $13.61 \pm 1.05^{\text {abef }}$ & 6.99 \\
\hline 50ng/ml rmIL-17 & $4.13 \pm 0.13$ & $3.57 \pm 1.34$ & $7.86 \pm 3.77^{\text {abce }}$ & $15.89 \pm 3.18^{\text {abcef }}$ & 17.17 \\
\hline 100ng/ml rmIL-17 & $3.94 \pm 0.77$ & $3.62 \pm 0.98$ & $8.27 \pm 2.47$ abcde & $17.17 \pm 1.13^{\text {abcdef }}$ & 38.32 \\
\hline $\mathrm{F}$ value & 0.56 & 0.24 & 2.95 & 9.69 & \\
\hline \multicolumn{6}{|c|}{ 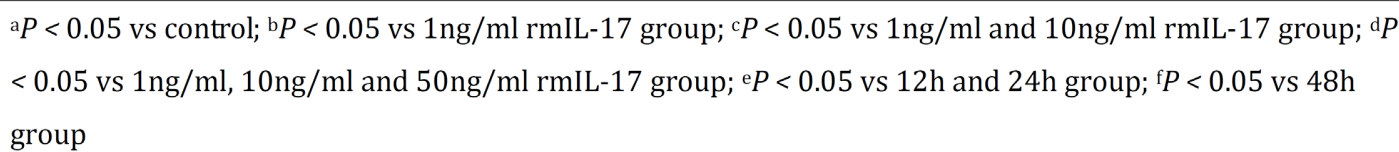 } \\
\hline
\end{tabular}

Fig. 7. Time course of the effect of different rmIL-17 concentrations on podocyte apoptosis.

Fig. 8. Expressions of WT1, nephrin, synaptopodin, podocalyxin, Fas and FasL mRNA from RT-PCR relative to the housekeeping gene, GAPDH; $P<0.05$ vs. ctr.

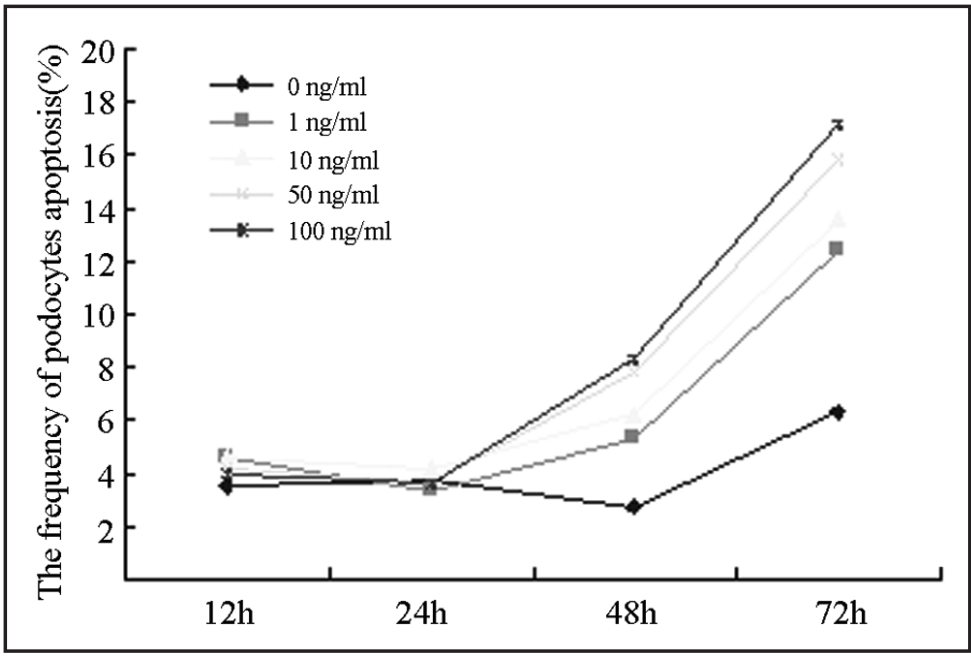

$\nabla$

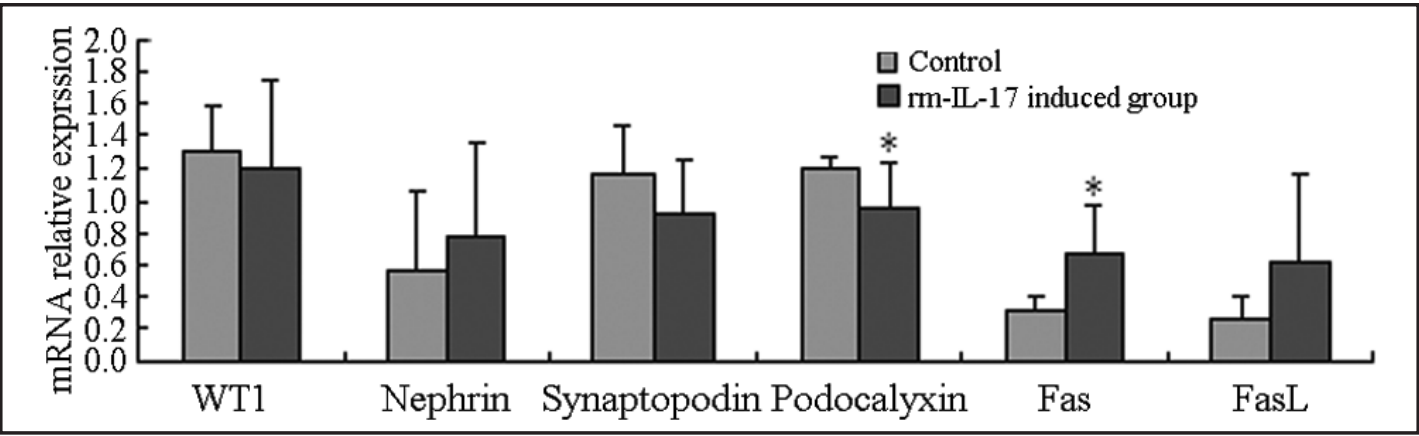

expression of podocalyxin was lower $(P<0.05)$. No statistical difference was observed in the mRNA expression levels of nephrin, WT1, synaptopodin, and FasL between the control and rmIL-17 exposed groups (see Fig. 8, $P>0.05$ ).

Protein expressions of Fas and FasL in podocytes induced by $I L-17$

Under basal conditions, podocytes express faint levels of Fas and FasL. After exposure to rmIL-17, a striking increase in Fas expression was found in the rmIL-17-induced group $(2.27 \pm 0.63)$ compared with the control group $(1.20 \pm 0.19)$ (see Fig. $9, P<0.01)$. However, no difference in FasL expression was observed between the rm1L-17-induced group $(0.67 \pm$ $0.56)$ and the control group $(0.60 \pm 0.12)$ (see Fig. $9, P>0.05)$. 


\section{Kidney Blood Pressure Research}

Fig. 9. FCM analysis of Fas and FasL in podocytes. A, C: Fas and FasL expression in the control group. B, D: Fas and FasL expression in the $100 \mathrm{ng} /$ ml rmIL-17-induced group.
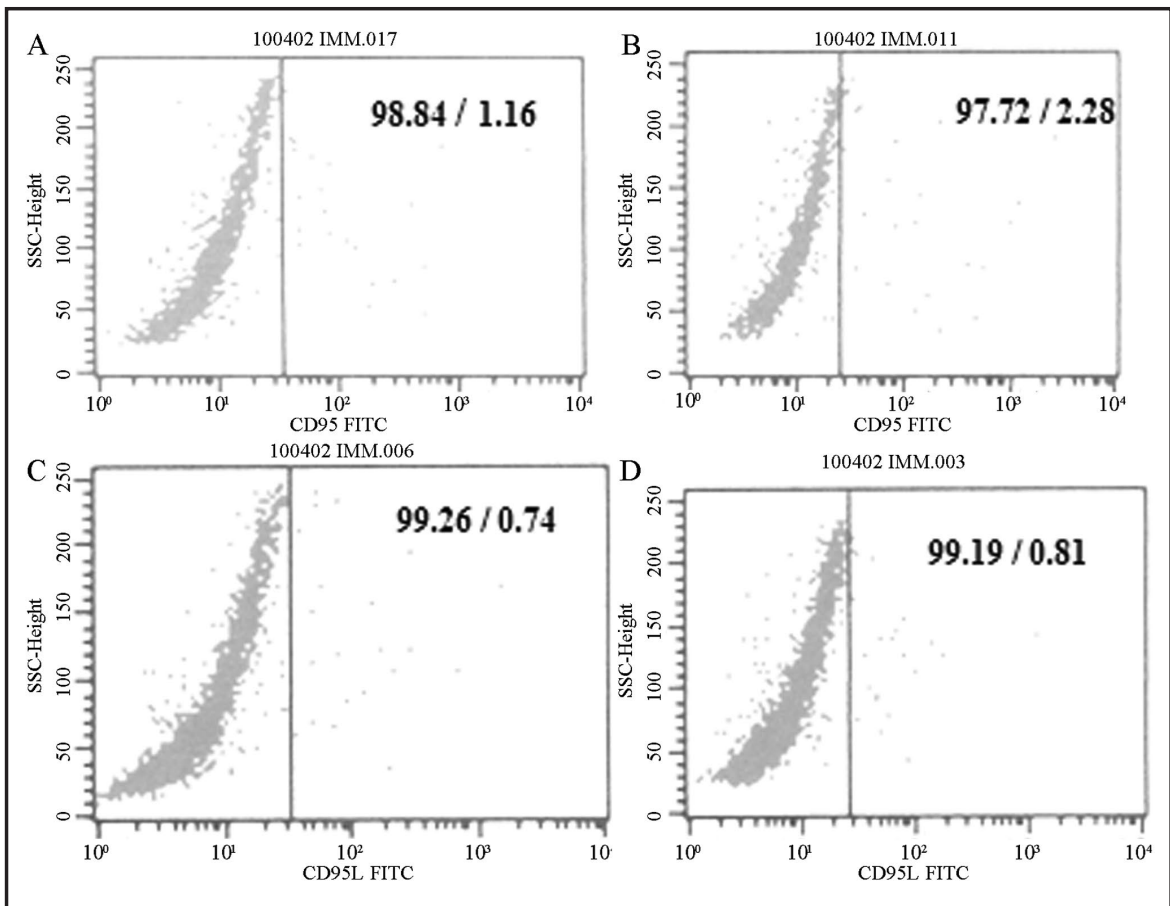

Fas protein expression in the kidney

In the control group, we discovered slight staining for Fas, but observed an obvious increase in Fas staining in the MCNS and FSGS group tissue samples $(P<0.01)$. The Fas expression in the FSGS kidney was lower than that in the MCNS group $(P<0.01$, Fig. 10). Major fibrosus and glomerulosclerosis of the renal parenchyma with FSGS with a reduction in the number of cells was observed, which was consistent with the decrease in Fas expression.

Caspase 8 expression in podocytes

In the control group, a small amount of caspase 8 was present in the cytoplasm of the podocytes $(80.00 \pm 12.05)$. Caspase 8 expression was induced in the podocytes by exposure to $100 \mathrm{ng} / \mathrm{ml} \mathrm{rmIL-17}(131.06 \pm 10.43)$ to a significant degree ( Figs. $11 \mathrm{~A}$ and $11 \mathrm{~B}, P<0.05$ ).

\section{Caspase 3 expression in podocytes}

No Caspase 3 active fragment was detected in the cytoplasm of control podocytes. After stimulation with $100 \mathrm{ng} / \mathrm{ml} \mathrm{rmIL-17}$, an obvious amount of caspase 3 active fragment was found (Figs. 11C and 11D).

WT1 expression in podocytes

No difference was observed in the WT1 expression between the unexposed and rmIL-17 exposed podocytes (52.73 \pm 3.16 vs $5.71 \pm 4.65$, respectively) (Fig. $11 \mathrm{E}$ and $11 \mathrm{~F}$, $P>0.05)$.

\section{Discussion}

Although we are aware of the rising incidence of chronic kidney disease, we are surprised that the cause of such a disease in adults is the occurrence of different renal diseases in childhood [11]. Given that PNS is a common cause of chronic kidney disease in children, early prevention and treatment are of great importance. A crucial step is to elucidate the pathogenesis of PNS to allow more targeted therapeutics. T cells are known to have an important function in PNS. Naive T cells can differentiate between various T cell subsets that 


\section{Kidney \\ Blood Pressure \\ Research}

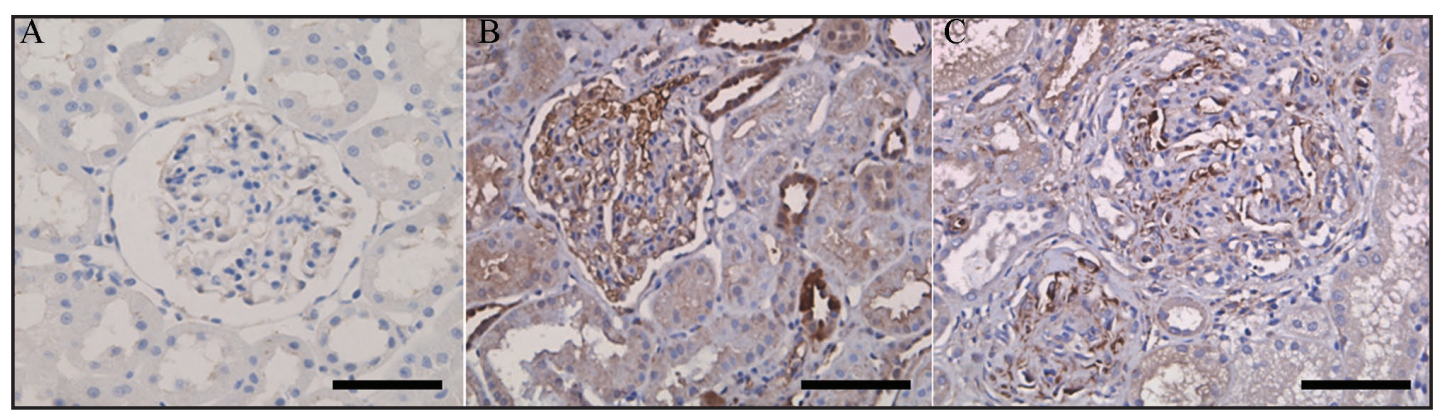

Fig. 10. Protein expression of Fas in the control group (A), MCNS group (B), and FSGS group (C) is indicated by the brown DAB staining. Magnification bar $=50 \mu \mathrm{m}$.

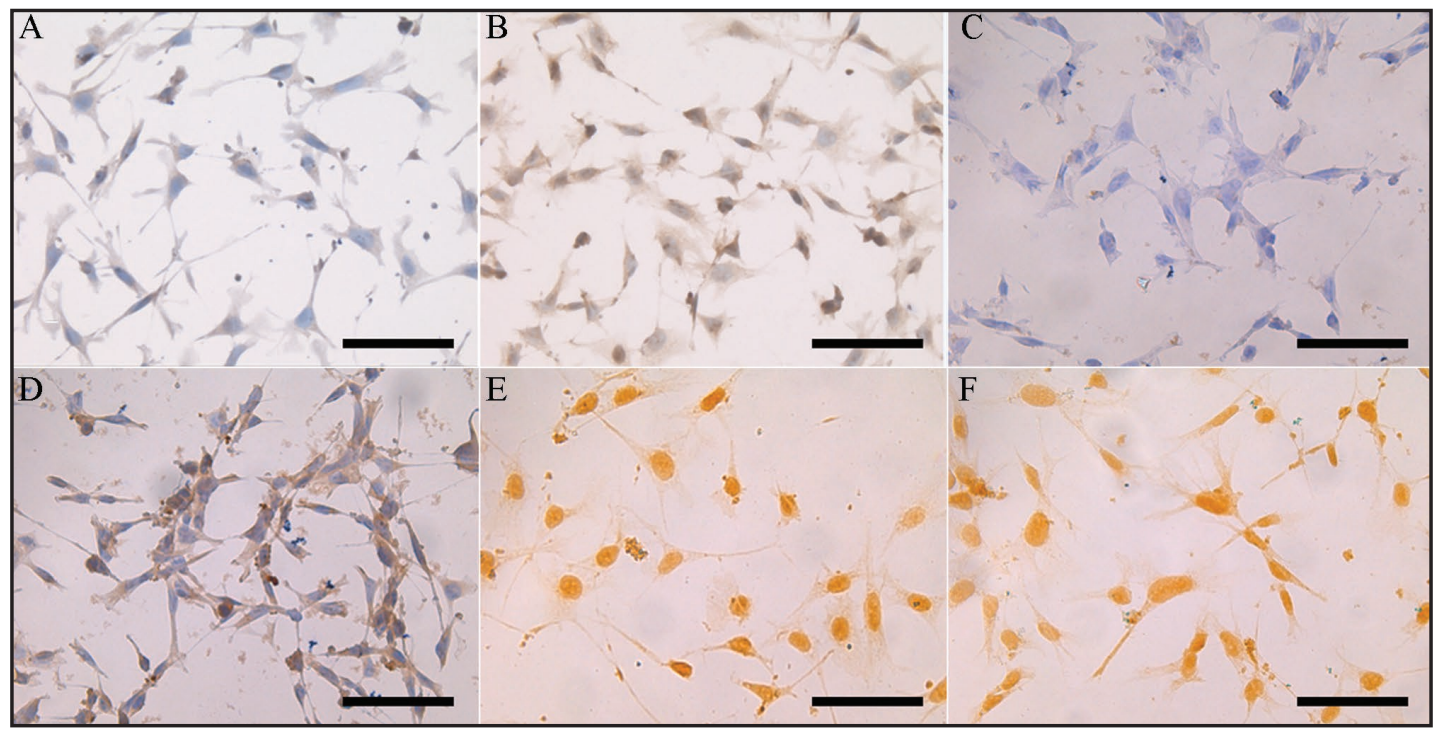

Fig. 11. Protein expression of Caspase 8, Caspase 3 active fragment, and WT1 in podocytes without and with exposure to $100 \mathrm{ng} / \mathrm{ml} \mathrm{rmIL-17}$ in $72 \mathrm{~h}$, as indicated by brown DAB staining. Magnification bar $=50$ $\mu \mathrm{m}$. A-B: Caspase 8 expression without (A) and with exposure to $100 \mathrm{ng} / \mathrm{ml} \mathrm{rmIL-17}$ (B).Brown represents Caspase 8; C-D: Caspase 3 active fragment expression without (C) and with exposure to $100 \mathrm{ng} / \mathrm{ml} \mathrm{rmIL-17}$ (D). Brown represents Caspase 3 active fragment; E-F: WT1 expression without (E) and with exposure to $100 \mathrm{ng} / \mathrm{ml} \mathrm{rmIL}-17$, yellowish-brown represents WT1; (F).

respond to different antigens and cytokines. IL-12 and IFN- $\gamma$ induce Th0 cells to differentiate between Th1 by way of the T-box transcription factor (T-bet), which mediates cell immunity. Th0 cells exposed to IL- 4 leads to GATA activation that causes differentiation into Th2 cells and promotes humoral immunity. Th17 has been described as a distinct subset from Th1 and Th2. Naive murine CD4 ${ }^{+}$T cells activated with TGF- $\beta$ and IL- 6 leads to the expression of retinoic acid-related orphan nuclear receptor $\gamma \mathrm{t}$ (ROR $\gamma \mathrm{t}$ ), which directs the differentiation program of helper cell Th17 cells [12]. In humans, IL-1 $\beta$, IL-6, and IL-23 all have a prominent function in Th17 differentiation [13,14], whereas TGF- $\beta 1$ can inhibit the development of human Th17 cells. Many scholars agree that Th17 cells have a key function in the onset and development of inflammatory and autoimmune diseases. In our study, we found evidence that Th17 contributes to the onset of PNS in children. In children with MCNS and NMCNS, increased Th17 cells were observed as well as elevated expression levels of IL-1 $\beta$, IL-6, IL23, and RORc, a correlation that indicates that Th17 may contribute to PNS pathogenesis 


\section{Kidney Blood Pressure Research}

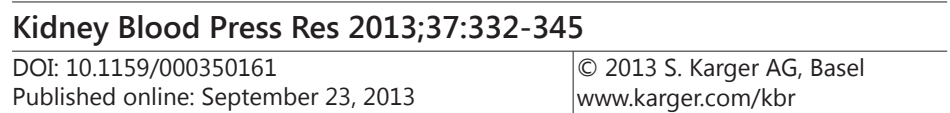

Published onlıne: September 23, 2013 www.karger.com/kbr

Wang/Li/Wang/Li/Yang/Wang/Tao: Role of Th17/IL-17 in the Pathogenesis of PNS

and proteinuria. Th17 cells and associated factors were obviously higher in NMCNS children than in MCNS children. It is possible that the Th17 cell level and amount of signaling are related to the pathological type of PNS, as well as to the sensitivity to GC and prognosis. Thus, we conducted a detailed study on the expression of IL-17 in a different pathological type of PNS. MCNS, which accounts for $80 \%$ of PNS cases, is the most common pathological type. In renal biopsy tissue from MCNS, the glomerular structure and morphology were normal by light microscopy and no evidence of inflammation was found. Mesangial proliferations were found in MsPGN with increased mesangial substrates. Glomerulosclerosis was the defining feature in FSGS. MCN, MsPGN, and FSGS pathological severity increased gradually along with the IL-17 expression, so we employed immunohistochemistry to identify the IL-17 and IL-1 $\beta$ expression in renal biopsy sections. No difference was found in the IL-17 and IL-1 $\beta$ expression between the MCNS group and the control group. The IL-17 and IL-1 $\beta$ expression was increased in the MsPGN group and further increased in the FSGS group.

Moreover, IL-17 expression had a positive correlation with the IL-1 $\beta$ expression in the FSGS groups. IL-17 expression was also positively related to GSI in FSGS, which leads us to hypothesize that elevated IL-17 expression may promote renal pathological injury. How did IL-17 cause kidney damage? Several researchers reported that IL-17 can induce renal tubular epithelial cells [15] and endothelial cells to express pro-inflammatory markers such as IL-1 $\beta$, TNF-a, and MCP-1. IL-17 also cooperates with these cytokines to promote the development of severe renal inflammation and eventual glomerulosclerosis. At the same time, IL-17 may up-regulate the expression of ICAM-1 [16] and activate the Th17 cells in the focal kidney.

Podocyte injury is a characteristic change nephritic syndrome. Our previous study found that Th17-IL17 expression in the peripheral blood and kidney tissue of the nephritic syndrome is significantly increased. No related reports have been found on whether Il-17 can damage podocytes and what their mechanism is.

Podocyte is a differentiated cell type in the renal viscera. When podocytes are injured, the podocyte foot process is broken and the podocyte detaches from the GMB. A mature podocyte has limited proliferation, so it cannot repair itself, which leads to protein leakage from the GMB. Thus, the functional integrity and number of podocytes are crucial to normal renal function. Podocyte process-related factors (such as nephrin and podocin) have significant roles in maintaining the normal filtration of the GMB. These factors are divided into three types based on their distribution in the podocyte process. The first type of factor is located in the apical area, which includes podocalyxin and podoplanin. Podocalyxin is a prominent protein in the construction of the glomerular anion protective screen. A decrease or loss of podocalyxin may fuse the podocyte processes and cause mass proteinuria [17]. The second type of factor is located in the slit diagram and includes nephrin, podocin, and actin. The loss or mutation of podocin has been shown to lead to FSGS or family nephrotic syndrome [18]. The last group of factors is located in the basement of podocyte processes, including $\alpha 3 \beta 1$-integrins and dystroglycan compounds. They are mainly joined to maintain the morphology of the podocytes, as well as the interaction between podocytes and the basement membrane. Except for WT1 (Wilms' tumor inhibitor gene) and synaptopodin, this group of factors contributes to the normal morphology and functioning of podocytes. WT1 is a cytoplasmic zinc-finger transcription factor with an expression that is decreased in FSGS [19]. Synaptopodin is an actin-binding protein that connects to the actin filament of podocyte processes and participates in regulating the morphology of such processes. In MCNS, congenital nephrotic syndrome, and FSGS, the synaptopodin expression is decreased [20]. A normal number of podocytes is significant in normal glomerular filtration.

Previous studies have shown that the decrease in podocyte number is associated with podocyte apoptosis or loss from the GMB [21, 22] and the onset of renal diseases [23]. A decrease in the total number of podocyte cells is closely correlated to the development of proteinuria and glomerulosclerosis [24, 25]. 


\section{Kidney Blood Pressure Research}

\begin{tabular}{l|l}
\hline Kidney Blood Press Res 2013;37:332-345 \\
\hline DOI: $10.1159 / 000350161$ & (C) 2013 S. Karger AG, Basel
\end{tabular}

Published online: September 23, 2013

www.karger.com/kbr

Wang/Li/Wang/Li/Yang/Wang/Tao: Role of Th17/IL-17 in the Pathogenesis of PNS

The mechanism of podocyte injury includes immune-mediated injury, mutation of podocyte factors, infection, high glucose, or hypertension. The abnormal expression of $\mathrm{T}$ cells and related factors have a key function in podocyte injury $[19,20]$. In this study, we found an increased number of Th17 cells and signaling in children with PNS. Th17 cells are recognized as a major type of T cell capable of producing IL-17, a cytokine cloned in 1995, although it remains unclear how IL-17 causes podocyte injury.

In our study, we discovered that IL-17 had no effect on the mRNA expression of nephrin, WT1, and synaptopodin, but observed a decreased expression of podocalyxin (see Fig. 8). Podocalyxin is a CD34-related sialomucin mainly expressed in podocytes, vascular endothelial cells, platelets, and hematopoietic precursor cells [26].

Podocalyxin has a negative charge that can protect protein from the filtration of GMB, but also maintains the intact SD of the podocyte [27]. The mechanism by which IL-17 mediates the decreased expression of podocalyxin requires further research.

We also found that IL-17 promoted podocyte apoptosis in a time- and dose-related manner. One previous study [28] reported that repeated injections of puromycin aminonucleoside (PAN) can induce podocyte injury, leading to a decrease in the number and density of podocytes, with resultant glomerulosclerosis. When $10 \%$ to $20 \%$ of the podocytes are lost or damaged, glomerulosclerosis develops, which indicates that the degree of podocyte loss has a close connection with the development of glomerulosclerosis. We found variable degrees of elevation in Th17 and related factor signaling between samples in the MCNS group and the NMCNS group, which could be related to the severity of renal tissue involvement in PNS.

However, the mechanism by which IL-17 induces podocyte apoptosis remains unknown. Inflammatory cytokines may induce muscle cell apoptosis via the Fas pathway [29]. The apoptosis receptor Fas, also known as APO-1 or CD95, belongs to the family of tumor necrosis factor receptors. Three repeated sequences with rich cysteine regions are found in the extracellular domains of Fas along with the intracellular death domain (DD). When Fas binds with its ligand FasL, a conformational change of the DD is observed. Activation of the DD region of Fas associated death domain (FADD) leads to the self-activation of Caspase 8 and Caspase 10, as well as the activation of Caspase 3, Caspase 6, and Caspase 10, which results in the death of the cell [30]. Fas is mainly expressed in the cytoplasmic membrane of T cells and B cells, whereas FasL is located in mature CD8+ T cells and CD4+ T cells. The podocyte expresses both Fas and FasL on the cytoplasmic surface [31], so we hypothesized that IL-17 may induce podocyte apoptosis through a Fas/FasL signaling pathway. Our study indicated that IL-17 can increase the Fas gene and protein expression levels in podocytes, with increased downstream apoptotic proteins, including Caspase 8 (see Fig. 11) and Caspase 3 eventually leading to increased apoptosis. IL-17-mediated apoptosis will further decrease the number of podocytes and damage the filtration barrier of the glomerulus and cause mass proteinuria.

\section{Conclusion}

Th17/IL-17 has a key function in the pathogenesis of children with PNS by decreasing the expression of podocalyxin and inducing podocyte apoptosis. This study provides theoretical evidence that by inhibiting the production of IL-17 or the cascade signal of IL-17, a therapeutic approach may be developed to treat children with PNS or prevent the disease.

\section{Conflict of Interests}

The authors have declared that no Conflict of interest exists. 


\section{Kidney \\ Blood Pressure Research}

\section{Acknowledgments}

This study was financially supported by the National Natural Science Foundation of China (grant no: 81070563 and 81200520 ).

\section{References}

1 Yang JY, Yao Y, Chinese Society of Pediatric Nephrology: Analysis of 1268 patients with chronic renal failure in childhood: a report from 91 hospitals in China from 1990 to 2002. Zhonghua Er Ke Zha Zhi 2004;42:724730.

-2 Rodriguez-Iturbe B, Herrera-Acosta J, Johnson RJ:Interstitial inflammation, sodium retention, and the pathogenesis of nephrotic edema: a unifying hypothesis. Kidney Int 2002;62:1379-1384.

-3 Ahmad H, Tejani A: Predictive value of repeat renal biopsies in children with nephrotic syndrome. Nephron 2000;84:342-346.

4 Shalhoub RJ: Pathogenesis of lipoid nephrosis: a disorder of T-cell function. Lancet 1974;2:556-560.

5 Lama G, Luongo I, Tirino G, Borriello A, Carangio C, Salsano ME: T-lymphocyte populations and cytokines in childhood nephrotic syndrome. Am J Kidney Dis 2002;39:958-965.

-6 Stachowski J, Krynicki T, Barth C, Runowski D, Lewandowska-Stachowiak M, Warzywoda A, Bortkiewicz E, Dobosz M, Maciejewski J: Dose the changed Th1/Th2 activity in children with the assessment of body water in children with nephrotic syndrome initial results. Pol Merkur Lekarski 2000;8:222-224.

7 Kaneko K, Tuchiva K, Fujinaga S, Kawamura R, Ohtomo Y, Shimizu T, Yamashiro Y: Th1/Th2 balance in childhood idiopathic nephrotic syndrome. Clin Nephrol 2002;58:393-397.

8 Shao XS, Yang XQ, Zhao XD, Li Q Xie YY, Wang XG, Wang M, Zhang W: The prevalence of Th17 cells and FOXP3 regulate T cells (Treg) in children with primary nephrotic syndrome. Pediatr Nephrol 2009;24:1683-1690.

-9 Rodriguez-Iturbe B, Quiroz Y, Shahkarami A, Li Z, Vaziri ND: Mycophenolate mofetil ameliorates nephropathy in the obese Zucker rat. Kidney Int 2005;68:1041-1047.

10 Shankland SJ, Pippin JW, Reiser J, Mundel P: Podocytes in culture: past, present, and future. Kidney Int 2007;72:26-36.

11 Levey AS, Eekardt KU, Tsukamoto Y, Levin A, Coresh J, Rossert J, De Zeeuw D, Hostetter TH, Lameire N, Eknoyan G: Definition and classification of chronic kidney disease: a position statement from Kidney Disease: Improving Global Outcome (KDIGO). Kidney Int 2005;67:2089-2100.

12 Ivanov II, McKenzie BS, Zhou L, Tadokoro CE, Lepelley A, Lafaille JJ, Cua DJ, Littman DR: The orphan nuclear receptor RORgammat directs the differentiation program of proinflammatory IL-17+ T helper cells. Cell 2006;126:1121-1123.

13 Wilson NJ, Boniface K, Chan JR, McKenzie BS, Blumenschein WM, Mattson JD, Basham B, Smith K, Chen T, Morel F, Lecron JC, Kastelein RA, Cua DJ, McClanahan TK, Bowman EP, de Waal Malefyt R: Development, cytokine profile and function of human interleukin 17-producing helper T cells. Nat Immunol 2007;8:950957.

14 Acosta-Rodriguez EV, Napolitani G, Lanzavecchia A, Sallusto F: Interleukins 1beta and 6 but not transforming growth factor-beta are essential for the differentiation of interleukin 17-producing human T helper cells. Nat Immunol 2007;8:942-949.

15 Woltman AM, de Haij S, Boonstra JG, Gobin SJ, Daha MR, van Kooten C: Interleukin-17 and CD40-ligand synergistically enhance cytokine and chemokine production by renal epithelial cells. J Am Soc Nephrol 2000;11:2044-2055.

16 Dong C: Th17 cells in development: an updated view of their molecular identity and genetic programming. Nat Rev Immunol 2008;8:337-348.

17 Kurihara H, Anderson JM, Kerjaschki D, Farquhar MG: The altered glomerular filtration slits seen in puromycin aminonucleoside nephrosis and protamine sulfate-treated rats contain the tight junction protein ZO-1. Am J Pathol 1992;141:805-816.

18 Mollet G, Ratelade J, Boyer O, Muda AO, Morisset L, Lavin TA, Kitzis D, Dallman MJ, Bugeon L, Hubner N, Gubler MC, Antignac C, Esquivel EL: Podocin Inactivation in Mature Kidneys Causes Focal Segmental Glomerulosclerosis and Nephrotic Syndrome. J Am Soc Nephrol 2009;20:2181-2189. 


\section{Kidney \\ Blood Pressure Research}

Wang/Li/Wang/Li/Yang/Wang/Tao: Role of Th17/IL-17 in the Pathogenesis of PNS

19 Mayo MW, Wang CY, Drouin SS, Madrid LV, Marshall AF, Reed JC, Weissman BE, Baldwin AS: WT1 modulates apoptosis by transcriptionally upregulating the bcl-2 proto-oncogene. EMBO J 1999;18:3990-4003.

20 Srivastava T, Garola RE, Whiting JM, Alon US: Synaptopodin expression in idiopathic nephrotic syndrome of childhood. Kidney Int 2001;59:118-125.

21 Ziyadeh FN, Wolf G: Pathogenesis of podocytopathy and proteinuria in diabetic glomerulopathy. Curr Diabetes Rev 2008;4:39-45.

-22 Hara M, Yanagihara T, Kihara I, Higashi K, Fujimoto K, Kajita T: Apical cell membranes are shed into urine from injured podocytes: a novel phenomenon of podocyte injure. J Am Soc Nephrol 2005;16:408-416.

-23 Ohtaka A, Ootaka T, Sato H, Ito S: Phenotypic change of glomerular podocytes in primary focal segmental glomerulosclerosis: developmental paradigm? Nephrol Dial Transplant 2002;17:11-15.

24 Macconi D, Bonomelli M, Benigni A, Plati T, Sangalli F, Longaretti L, Conti S, Kawachi H, Hill P, Remuzzi G, Remuzzi A: Pathophysiologic implications of reduced podocyte number in a rat model of progressive glomerular injury. Am J Pathol 2006;168:42-45.

25 Lemley KV, Lafayette RA, Safai M, Derby G, Blouch K, Squarer A, Myers BD: Podocytopenia and disease severity in IgA nephropathy. Kidney Int 2002;61:1475-1485.

26 Sassetti C, Tangemann K, Singer MS, Kershaw DB, Rosen SD: Identification of podocalyxin-like protein as a high endothelial venule ligand for L-selectin: parallels to CD34. J Exp Med 1998;187:1965-1975.

27 Takeda T, Go WY, Orlando RA, Farquhar MG: Expression of podocalyxin inhibits cell-cell adhesion and modifies junctional properties in Madin-Darby canine kidney cells. Mol Biol Cell 2000;11:3219-3232.

-28 Kim YH, Goyal M, Kurnit D, Wharram B, Wiggins J, Holzman L, Kershaw D, Wiggins R: Podocyte depletion and glomerulosclerosis have a direct relationship in the PAN-treated rat. Kidney Int 2001;60:957-968.

-29 Kondo M, Murakawa Y, Harashima N, Kobayashi S, Yamaguchi S, Harada M: Roles of proinflammatory cytokines and the Fas/Fas ligand interaction in the pathogenesis of inflammatory myopathies. Immunology 2009;128:e589-599.

-30 Gerhing S, Rottmann S, Menkel AR, Mertsching J, Krippner-Heidenreich A, Lüscher B: Inhibition of proliferation and apoptosis by the transcriptional repressor Mad 1.Repression of Fas-induced caspase-8 activation. J Biol Chem 2000;275:10413-10420.

-31 Wang C, Peng H, Tang H, Liu X, Chen Z, Lou T, Yu X: Serum IgA1 from IgA nephropathy patients induces apoptosis in podocytes through direct and indirect pathways. Clin Invest Med 2007;30:E240-E249. 